\title{
Asaccharobacter celatus gen. nov., sp. nov., isolated from rat caecum
}

Correspondence
Kimiko Minamida
kimiko-m@chem.agr.hokudai.ac.jp

The family Coriobacteriaceae was proposed by Stackebrandt et al. (1997) and, at the time of writing, comprises the following eight genera: Olsenella (Dewhirst et al., 2001), Atopobium (Collins \& Wallbanks, 1992), Slackia (Wade et al., 1999), Cryptobacterium (Nakazawa et al., 1999), Eggerthella (Kageyama et al., 1999; Wade et al., 1999), Denitrobacterium (Anderson et al., 2000), Coriobacterium (Haas \& König, 1988) and Collinsella (Kageyama \& Benno, 2000). A Gram-positive bacterium, designated strain $\mathrm{do} 3^{\mathrm{T}}$, capable of converting daidzein to equol via dihydrodaidzein was isolated from the caecal content of a rat (Minamida et al., 2006a). The 16S rRNA gene sequence (1428 bp) of the novel strain showed highest similarity (99\%) with that of the human intestinal bacterium SNUJulong 732 (GenBank accession no. AY310748), which was capable of metabolizing dihydrodaidzein to $S$-equol (Wang et al., 2005). The levels of similarity with respect to members of the three recognized species of the genus Eggerthella, Eggerthella sinensis $\mathrm{HKU}_{14}^{\mathrm{T}}$ (AY321958), Eggerthella hongkongensis $\mathrm{HKU}_{10}^{\mathrm{T}} \quad(\mathrm{AY} 288517)$ and Eggerthella lenta ATCC $25559^{\mathrm{T}}$ (AF292375), were in the range of 93 to $94 \%$. On the basis of the phylogenetic analysis, strain $\mathrm{do} 03^{\mathrm{T}}$ differed from members of the genus Eggerthella and belonged to a novel genus of the family Coriobacteriaceae (Minamida et al., 2006a). In this paper,

The GenBank/EMBL/DDBJ accession number for the 16S rRNA gene sequence of strain doO3 ${ }^{\top}$ is $A B 266102$. we describe additional taxonomic characteristics of the novel strain in comparison with phylogenetically close genera, and classify it as a novel genus and species within the family Coriobacteriaceae.

Cell morphology and size after anaerobic cultivation at $37^{\circ} \mathrm{C}$ for 2 days in Gifu anaerobic medium (GAM) broth (Nissui) were examined using phase-contrast microscopy (Nikon). Gram-staining was performed with 3-day-old culture by using a neo-B\&M kit (Wako). Colonial morphologies were viewed after cultivation on GAM agar at $37^{\circ} \mathrm{C}$ for 2 days in an anaerobic chamber $\left(\mathrm{N}_{2} / \mathrm{H}_{2} / \mathrm{CO}_{2}, 85: 5: 10\right.$; Coy Laboratory). Biochemical traits were determined using both conventional methods (Holdeman et al., 1977) and the API $50 \mathrm{CH}$ system (bioMérieux). Enzyme activities were analysed with the API ZYM system (bioMérieux) using bacteria harvested from GAM broth supplemented with $0.5 \%$ arginine. Cells were incubated anaerobically at $37^{\circ} \mathrm{C}$ for $48 \mathrm{~h}$ (API $50 \mathrm{CH}$ ) and $4 \mathrm{~h}$ (API ZYM). For the analysis of short-chain fatty acids by HPLC (Minamida et al., 2006b), the novel strain was grown in PYG broth (Holdeman et al., 1977). To investigate the effects of arginine on growth, cells precultured in GAM broth were inoculated $(1 \%, \mathrm{v} / \mathrm{v})$ into GAM broth supplemented with $0,0.5,1.0$ and $2.0 \%$ arginine $(\mathrm{pH} 7.0)$ and then incubated anaerobically at $37^{\circ} \mathrm{C}$. Absorbance values $\left(\mathrm{OD}_{600}\right)$ were measured using Spectronic 20D + spectrophotometers (Thermo Electron). Fatty acid methyl esters were obtained from wet biomass (approx. $40 \mathrm{mg}$ ) by saponification, methylation and extraction 
according to the method described by Miller (1982), modified as described by Kuykendall et al. (1988). The fatty acids were separated according to the method described by Nishimukai et al. (2003) and were identified using authentic fatty acid methyl ester standards (Supelco). DNA G + C contents were determined using HPLC (Tamaoka \& Komagata, 1984) after enzyme digestion of DNA to the deoxyribonucleosides. DNA was extracted and purified as described by Saito \& Miura (1963). An equimolar mixture of four deoxyribonucleotides from a GC kit (Yamasa Shoyu) was used as the quantitative standard. Isoprenoid quinones and diamino acids were investigated by the TechnoSuruga Laboratory Co., Ltd (Shizuoka, Japan). Isoprenoid quinones were extracted as described by Nishijima et al. (1997) and analysed using HPLC apparatus (Waters) equipped with an Inertsil ODS- 3 column $(4.6 \times 150 \mathrm{~mm}$; GL Science $)$ and a photodiode array detector $(210-400 \mathrm{~nm}$; Waters). The elution solvent was a mixture of methanol and 2-propanol $(3: 1, \mathrm{v} / \mathrm{v})$. Cell-wall peptidoglycan was prepared and hydrolysed as described by Komagata \& Suzuki (1987). The amino acid composition was determined by HPLC using the method of the TechnoSuruga Laboratory. Samples were derivatized with phenylisothiocyanate and UV detection (at $254 \mathrm{~nm}$ ) was used.

The novel strain was found to be an obligately anaerobic, Gram-positive, rod-shaped, non-spore-forming bacterium. After 2 days incubation on GAM plates, colonies were $1 \mathrm{~mm}$ in diameter, smooth, clear and colourless. The strain did not grow in the presence of oxygen. Catalase was not produced and nitrate was not reduced. The cell-wall peptidoglycan contained meso-diaminopimelic acid, alanine and glutamic acid (molar ratio approx. $0.9: 1.7: 1.0$ ), indicating the $\mathrm{A} 1 \gamma$ type polymer (Schleifer \& Kandler, 1972). Two unidentified quinones (91.9 and $4.1 \%$ ) and one unidentified ubiquinone $(4.0 \%)$ were detected. The unidentified quinones were similar to menaquinones in the UV-spectrum pattern but differed from the saturated and unsaturated menaquinones found in actinobacteria to date. They were not methylmenaquinones, demethylmenaquinones, ubiquinones or rhodoquinones. After $22 \mathrm{~h}$ cultivation, the $\mathrm{OD}_{600}$ values (means $\pm \mathrm{SD}$ ) in GAM broth supplemented with $0,0.5,1.0$ and $2.0 \%$ arginine were $0.24(\mathrm{pH} 7.1), 0.85 \pm 0.02(\mathrm{pH} 7.8)$,
$1.16 \pm 0.01(\mathrm{pH} 8.0)$ and $1.09 \pm 0.05(\mathrm{pH} 8.1)$, respectively. The optimum arginine concentration was $1.0 \%$. The novel strain tested negative for all carbohydrates in the API $50 \mathrm{CH}$ system and showed strong naphthol-AS-BI-phosphohydrolase activity, medium acid phosphatase activity and weak alkaline phosphatase and esterase (C4) activities.

The strain differed from closely related genera in the family Coriobacteriaceae with validly published names in terms of the features listed in Table 1. On the basis of the results of the 16S rRNA gene analysis (Minamida et al., 2006a) and the differences in phenotypic characteristics (Table 1), strain do $03^{\mathrm{T}}$ represents a novel genus and species in the family Coriobacteriaceae, for which the name Asaccharobacter celatus gen. nov., sp. nov. is proposed.

\section{Description of Asaccharobacter gen. nov.}

Asaccharobacter (A.sac.cha.ro.bac'ter. Gr. pref. $a$ - not; Gr. n. saccharon sugar; N.L. masc. n. bacter a rod; N.L. masc. n. Asaccharobacter rod that does not digest sugar).

Cells are Gram-positive, rod-shaped and non-sporing. Obligately anaerobic and catalase-negative. Asaccharolytic; produce trace amounts of organic acids (lactic, acetic and succinic) in medium containing peptone, yeast extract and glucose. Growth is enhanced in the presence of arginine, but not with Tween 80. Can grow in $20 \%$ bile. Cell-wall peptidoglycan contains meso-diaminopimelic acid, alanine and glutamic acid. The predominant cellular fatty acid is $\mathrm{C}_{18: 1}$ cis9. The predominant lipoquinone is an unidentified quinone that is not menaquinone, methylmenaquinone, demethylmenaquinone, ubiquinone or rhodoquinone. The DNA G $+\mathrm{C}$ content is approximately $63 \mathrm{~mol} \%$. The type species is Asaccharobacter celatus. The genus Asaccharobacter is a member of the family Coriobacteriaceae.

\section{Description of Asaccharobacter celatus sp. nov.}

Asaccharobacter celatus (ce.la'tus. L. masc. adj. celatus conceal, hide, keep secret).

In addition to possessing the characteristics given in the genus description, cells are $0.45 \mu \mathrm{m}$ in width and

Table 1. Differential phenotypic characteristics for strain do0 $03^{\top}$ and closely related genera

Taxa: 1, strain $\operatorname{do}^{\mathrm{T}}{ }^{\mathrm{T}}$ (data from this study); 2, Eggerthella (Kageyama et al., 1999; Lau et al., 2004; Moore \& Holdeman-Moore, 1986; Wade et al., 1999); 3, Denitrobacterium (Anderson et al., 2000). +, Positive; -, negative; ND, not determined.

\begin{tabular}{|lccc|}
\hline Characteristic & $\mathbf{1}$ & $\mathbf{2}$ & $\mathbf{3}$ \\
\hline Organic acids & Acetic acid, lactic acid, succinic acid & (Acetic acid, lactic acid, succinic acid) & ND \\
Cell-wall diamino acid & meso-Diaminopimelic acid & LL-Diaminopimelic acid & ND \\
Major cellular fatty acids & $\mathrm{C}_{18: 1}$ cis 9 & ${\text { Branched } \mathrm{C}_{15: 0}}$ & MK-6, MMK-6 \\
Major quinone & Unknown $\dagger$ & 62 & ND \\
DNA G+C content $(\mathrm{mol} \%)$ & 63 & $56-60$ \\
\hline
\end{tabular}

${ }^{\star}$ Products in parentheses indicate strain variation.

$\dagger$ Major quinone was not menaquinone, methylmenaquinone, demethylmenaquinone, ubiquinone or rhodoquinone. 
2.3-2.7 $\mu \mathrm{m}$ in length. Colonies are smooth, clear and colourless on GAM agar, reaching $1 \mathrm{~mm}$ in diameter after cultivation at $37{ }^{\circ} \mathrm{C}$ for 2 days. Does not reduce nitrate. Cells do not produce acid from or show negative test results in the API $50 \mathrm{CH}$ system with the following substrates: glycerol, glucose, erythritol, D-arabinose, Larabinose, ribose, $\mathrm{D}$-xylose, L-xylose, adonitol, methyl $\beta$-Dxyloside, galactose, fructose, mannose, sorbose, rhamnose, dulcitol, inositol, mannitol, sorbitol, methyl $\alpha$-D-mannoside, methyl $\alpha$-D-glucoside, $N$-acetylglucosamine, amygdalin, arbutin, aesculin, salicin, cellobiose, maltose, lactose, melibiose, sucrose, trehalose, inulin, melezitose, raffinose, starch, glycogen, xylitol, gentiobiose, D-turanose, D-lyxose, D-tagatose, D-fucose, L-fucose, D-arabitol, L-arabitol, gluconate, 2-ketogluconate and 5-ketogluconate. Cells show strong naphthol-AS-BI-phosphohydrolase activity, medium acid phosphatase activity and weak alkaline phosphatase and esterase (C4) activities, but do not show any of the following activities: esterase lipase (C8), lipase (C14), leucine arylamidase, valine arylamidase, cystine arylamidase, trypsin, $\alpha$-chymotrypsin, $\alpha$-galactosidase, $\beta$-galactosidase, $\beta$-glucuronidase, $\alpha$-glucosidase, $\beta$-glucosidase, $N$ acetyl- $\beta$-glucosaminidase, $\alpha$-mannosidase or $\alpha$-fucosidase. Capable of converting daidzein to equol. The major cellular fatty acids are $\mathrm{C}_{18: 1}$ cis $9(54.0 \%), \mathrm{C}_{18: 0}(11.7 \%)$ and $\mathrm{C}_{16: 0}$ $(8.4 \%)$. The DNA G+C content is $63 \mathrm{~mol} \%$.

The type strain, do03 ${ }^{\mathrm{T}}\left(=\mathrm{JCM} 14811^{\mathrm{T}}=\mathrm{DSM} 18785^{\mathrm{T}}=\right.$ AHU $1763^{\mathrm{T}}$ ), was isolated from the caecal content of a rat.

\section{Acknowledgements}

The authors gratefully acknowledge Mr Ongol Martin Patrick for his help during the preparation of this article.

\section{References}

Anderson, R. C., Rasmussen, M. A., Jensen, N. S. \& Allison, M. J. (2000). Denitrobacterium detoxificans gen. nov., sp. nov., a ruminal bacterium that respires on nitrocompounds. Int J Syst Evol Microbiol 50, 633-638.

Collins, M. D. \& Wallbanks, S. (1992). Comparative sequence analyses of the 16S rRNA genes of Lactobacillus minutus, Lactobacillus rimae and Streptococcus parvulus: proposal for the creation of a new genus Atopobium. FEMS Microbiol Lett 74, 235-240.

Dewhirst, F. E., Paster, B. J., Tzellas, N., Coleman, B., Downes, J., Spratt, D. A. \& Wada, W. G. (2001). Characterization of novel human oral isolates and cloned 16S rDNA sequences that fall in the family Coriobacteriaceae: description of Olsenella gen. nov., reclassification of Lactobacillus uli as Olsenella uli comb. nov. and description of Olsenella profusa sp. nov. Int J Syst Evol Microbiol 51, 1797-1804.

Haas, F. \& König, H. (1988). Coriobacterium glomerans gen. nov., sp. nov. from the intestinal tract of the red soldier bug. Int J Syst Bacteriol 38, 382-384.

Holdeman, L. V., Cato, E. P. \& Moore, W. E. C. (1977). Anaerobe Laboratory Manual, 4th edn. Blacksburg, VA: Virginia Polytechnic Institute and State University.

Kageyama, A. \& Benno, Y. (2000). Emendation of genus Collinsella and proposal of Collinsella stercoris sp. nov. and Collinsella intestinalis sp. nov. Int J Syst Evol Microbiol 50, 1767-1774.
Kageyama, A., Benno, Y. \& Nakase, T. (1999). Phylogenetic evidence for the transfer of Eubacterium lentum to the genus Eggerthella as Eggerthella lenta gen. nov., comb. nov. Int J Syst Bacteriol 49, $1725-1732$.

Komagata, K. \& Suzuki, K. (1987). Lipid and cell-wall analysis in bacterial systematics. Methods Microbiol 19, 161-207.

Kuykendall, L. D., Roy, M. A., O'Neill, J. J. \& Devine, T. E. (1988). Fatty acids, antibiotic resistance, and deoxyribonucleic acid homology groups of Bradyrhizobium japonicum. Int J Syst Bacteriol 38, 358-361.

Lau, S. K., Woo, P. C., Woo, G. K., Fung, A. M., Wong, M. K., Chan, K. M., Tam, D. M. \& Yuen, K. Y. (2004). Eggerthella hongkongensis sp. nov. and Eggerthella sinensis sp. nov., two novel Eggerthella species, account for half of the cases of Eggerthella bacteremia. Diagn Microbiol Infect Dis 49, 255-263.

Miller, L. T. (1982). Single derivatization method for routine analysis of bacterial whole-cell fatty acid methyl esters, including hydroxy acids. J Clin Microbiol 16, 584-586.

Minamida, K., Tanaka, M., Abe, A., Sone, T., Tomita, F., Hara, H. \& Asano, K. (2006a). Production of equol from daidzein by a grampositive rod bacterium isolated from rat intestine. J Biosci Bioeng 102, 247-250.

Minamida, K., Asakawa, C., Sujaya, I. N., Kaneko, M., Abe, A., Sone, T., Hara, H., Asano, K. \& Tomita, F. (2006b). Effects of long-term ingestion of difructose anhydride III (DFA III) on intestinal bacteria and bile acid metabolism in humans. J Biosci Bioeng 101, 149-156.

Moore, W. E. C. \& Holdeman-Moore, L. V. (1986). Genus Eubacterium Prévot 1938. In Bergey's Manual of Systematic Bacteriology, vol. 2, pp. 1353-1373. Edited by P. H. A. Sneath, N. S. Mair, M. E. Sharpe \& J. G. Holt. Baltimore: Williams \& Wilkins.

Nakazawa, F., Poco, S. E., Ikeda, T., Sato, M., Kalfas, S., Sundqvist, G. \& Hoshino, E. (1999). Cryptobacterium curtum gen. nov., sp. nov., a new genus of gram-positive anaerobic rod isolated from human oral cavities. Int J Syst Bacteriol 49, 1193-1200.

Nishijima, M., Araki-Sakai, M. \& Sano, H. (1997). Identification of isoprenoid quinones by frit-FAB liquid chromatography-mass spectrometry for the chemotaxonomy of microorganisms. J Microbiol Methods 28, 113-122.

Nishimukai, M., Hara, H. \& Aoyama, Y. (2003). Enteral administration of soybean lecithin enhanced lymphatic absorption of triacylglycerol in rats. Br J Nutr 90, 565-571.

Saito, H. \& Miura, K. (1963). Preparation of transforming deoxyribonucleic acid by phenol treatment. Biochim Biophys Acta 72, 619-629.

Schleifer, K. H. \& Kandler, O. (1972). Peptidoglycan types of bacterial cell walls and their taxonomic implications. Bacteriol Rev 36, 407-477.

Stackebrandt, E., Rainey, F. A. \& Ward-Rainey, N. L. (1997). Proposal for a new hierarchic classification system, Actinobacteria classis nov. Int J Syst Bacteriol 47, 479-491.

Tamaoka, J. \& Komagata, K. (1984). Determination of DNA base composition by reversed-phase high-performance liquid chromatography. FEMS Microbiol Lett 25, 125-128.

Wade, W. G., Downes, J., Dymock, D., Hiom, S. J., Weightman, A. J., Dewhirst, F. E., Paster, B. J., Tzellas, N. \& Coleman, B. (1999). The family Coriobacteriaceae: reclassification of Eubacterium exiguum (Poco et al. 1996) and Peptostreptococcus heliotrinreducens (Lanigan 1976) as Slackia exigua gen. nov., comb. nov. and Slackia heliotrinireducens gen. nov., comb. nov., and Eubacterium lentum (Prevot 1938) as Eggerthella lenta gen. nov., comb. nov. Int J Syst Bacteriol 49, 595-600.

Wang, X. L., Hur, H. G., Lee, J. H., Kim, K. T. \& Kim, S. I. (2005). Enantioselective synthesis of $S$-equol from dihydrodaidzein by a newly isolated anaerobic human intestinal bacterium. Appl Environ Microbiol 71, 214-219. 